\title{
PENGARUH MODEL PEMBELAJARAN GROUP INVESTIGATION TERHADAP KEMAMPUAN PEMECAHAN MASALAH SISWA KELAS VIII MTSN KABUPATEN KERINCI
}

\author{
Febria Ningsih \\ Institut Agama Islam Negeri Kerinci, Jalan Kapten Muradi Kota Sungai Penuh, Jambi. 37112 - Indonesia \\ fbningsih@yahoo.com
}

\begin{abstract}
Problem solving skill is one of any skills that have mastered by the students. For master it, cooperative learning model is a solution especially group investigation model. This research aims to know the effect of group investigation model to the students' problem solving skill. This research done by using a quasy-experimental in whole state islamic junior high school (MTsN) in Kerinci regency except excelent group at MTsN Kemantan and MTsN Air Hangat. The students of VIIID MTsNegeri Penawar and the students of VIIID MTsNegeri Semerah were choosen as experimental and control group. The research instrumentwas testto measure students' mathematical problem solving skill. The data analyzed by using Mann Whitney U test. The result of data analysis showed that students's that attend the learning by using group investigation had mathematical problem solving skill better than the students in another group.
\end{abstract}

Keywords: teaching and learning model, group investigation model, mathematical problem solving skill

\begin{abstract}
Abstrak
Kemampuan pemecahan masalah merupakan kemampuan matematis yang harus dikuasai oleh siswa. Salah satu usaha yang dapat dilakukan adalah dengan menerapkan model pembelajaran kooperatif tipe group investigation. Penelitian ini bertujuan untuk melihat pengaruh model pembelajatan group invertigation terhadap kemampuan pemecahan masalah matematis siswa.Jenis penelitian merupakan penelitian kuasi eksperimen dengan populasi siswa kelas VIII MTs Negeri di Kabupaten Kerinci kecuali kelas unggul di MTsN Kemantan dan MTsN Air Hangat.Siswa kelas VIIID MTsNegeri Penawar dan siswa VIIID MTsNegeri Semerah masing-masing terpilih sebagai kelas eksperimen dan kelas kontrol melalui teknik sampel acak. Instrumen penelitian adalah tes kemampuan pemecahan masalah.Analisis data dilakukan dengan menggunakan uji Mann Whitney U.Hasil analisis data menunjukkan bahwa pemecahan masalah siswa yang mengikuti pembelajaran kooperatif tipe group investigationlebih tinggi dari kemampuan pemecahan masalahsiswa yang mengikuti pembelajaran biasa.
\end{abstract}

Kata kunci: model pembelajaran, group investigation, kemampuan pemecahan masalah matematis

Matematika tidak hanya sebatas seperangkat pengetahuan, definisi dan teori yang kaku tetapi juga dapat digunakan untuk menyelesaikan berbagai permasalahan yang dihadapi oleh manusia. Perkembangan proses pembelajaran matematika di Indonesia terbilang sangat memprihatinkan (Prahmana, 2015). Penguasaan terhadap matematika sebagai ilmu harus berbanding lurus dengan penguasaan terhadap kemampuan matematis terutama kemampuan pemecahan masalah, karena salah satu aspek yang perlu dikembangkan dalam pembelajaran matematika adalah kemampuan pemecahan masalah (Pranata, 2016). Pemecahan masalah merupakan hal penting dalam pembelajaran matematika (Meditamar, Gunawan, Oktafia \& Nurmailis, 2017). Wahyudi dalam Asnawati, Sanusi \& Noto (2018) menyatakan bahwa pemecahan masalah bukan hanya diajarkan dan digunakan dalam matematika tetapi juga pada masalah keseharian. Masalah dalam matematika tidak bisa diselesaikan dengan 1 atau 2 cara yang sudah diketahui (Ahmad, Deswita, Ningsih \& Syafriadi, 2017). Sedangkan menurut NCTM (2000), memecahkan masalah bukan hanya merupakan tujuan dari belajar matematika tetapi juga sarana utama untuk bekerja dalam matematika. Dengan memecahkan masalah matematika, siswa akan memperoleh kebiasaan yang baik berupa rasa ingin tahu yang tinggi, kegigihan, dan kepercayaan diri 
saat berada dalam situasi yang berbeda. Hal ini menunjukkan betapa pentingnya kemampuan dalam pemecahan masalah.

Untuk mencapai tujuan pembelajaran matematika yang dapat melatih siswa berpikir logis, kritis dan mampu memecahkan masalah (Wulansari, Putra, Rusliah \& Habibi, 2019) proses pembelajaran harus terus dibenahi, mulai dari pembaharuan kurikulum, peningkatan kualitas guru matematika serta perbaikan sarana belajar. Akan tetapi berbagai upaya yang telah dilakukan belum memberikan hasil yang memuaskan. Permasalahan yang terjadi selama ini tidak hanya berasal dari faktor siswa saja tetapi juga tidak terlepas dari faktor tenaga pendidik (Ulandari, Putri, Ningsih \& Putra, 2019). Kenyataan di lapangan berbeda dengan yang diharapkan, kemampuan pemecahan masalah siswa masih rendah. Salah satu kemampuan pemecahan masalah yaitu mampu menyelesaikan permasalahan non rutin. Masalah non rutin adalah masalah dengan prosedur penyelesaian yang tidak biasa dilakukan atau memerlukan perencanaan terhadap suatu penyelesaian, tidak hanya menggunakan rumus, teorema, atau dalil (Lestari dan Yudhanegara, 2015). Sedangkan menurut sunendar (2017) suatu pertanyaan dapat dikatakan sebagai suatu masalah jika pertanyaan tersebut menunjukkan adanya suatu tantangan.

Indikasi rendahnya kemampuan pemecahan masalah siswa terlihat saat siswa diberikan suatu permasalahan yang non rutin. Jika diberikan permasalahan non rutin siswa bingung untuk menyelesaikannya karena tidak terlatih untuk itu. Sebagian besar siswa hanya mampu menyelesaikan soal atau permasalahan yang persis sama dengan yang telah dicontohkan oleh guru. Siswa tidak terbiasa berfikir secara sistematis terhadap langkah-langkah yang harus dilakukan untuk menyelesaikan masalah. Hasil tes kemampuan pemecahan masalah pada siswa MTsN di Kabupaten Kerinci menunjukkan bahwa sebagian besar siswa tidak mampu menyelesaikan masalah dengan baik. Kesalahan terjadi karena siswa tidak terbiasa menyatakan unsur-unsur yang diketahui dan ditanya pada soal. Hal ini menyebabkan siswa salah mengartikan maksud soal sehingga membawa mereka pada strategi dan jawaban yang salah. Berdasarkan hasil penskoran lembar jawaban siswa, skor rata-rata yang diperoleh siswa terpaut jauh dari skor maksimal yang seharusnya diperoleh yaitu 8. Hasil tes kemampuan pemecahan masalah siswa kelas VIII MTs Negeri di Kabupaten Kerinci dapat dilihat pada Tabel 1.

Tabel 1.

Skor Rata-rata Soal Tes Kemampuan Pemecahan Masalah

\begin{tabular}{llcc}
\hline No. & Nama Sekolah & Jumlah Siswa & Skor Rata-rata \\
\hline 1. & MTsN Semerah & 20 & 3,47 \\
\hline 2. & MTsN Kemantan & 15 & 3,10 \\
\hline 3. & MTsN Penawar & 20 & 3,28 \\
\hline
\end{tabular}

Tes kemampuan pemecahan masalah tersebut hanya diberikan pada siswa yang mempunyai hasil belajar matematika relatif tinggi dibandingkan siswa yang lain berdasarkan data nilai ujian matematika sebelumnya. Hal ini dilakukan dengan asumsi jika siswa yang mempunyai hasil belajar yang tinggi 
terbukti memperlihatkan kemampuan pemecahan masalah yang rendah maka siswa lain juga mengalami hal yang sama atau bahkan lebih buruk.

Banyak faktor yang dapat mempengaruhi tinggi rendahnya kemampuan pemecahan masalah siswa baik proses pembelajaran maupun siswa itu sendiri. Salah satu faktor yang dapat dimanipulasi sedemikian rupa untuk meningkatkan kemampuan pemecahan masalah siswa adalah proses pembelajaran melalui penerapan model pembelajaran Group Investigation. Menurut Mushoddik, Utaya \& Budijanto (2016) “Group Investigation diyakini dapat meningkatkan keterlibatan siswa secara keseluruhan dalam aktivitas memberikan wacana, asumsi dan memberikan jawaban”. Senada dengan hal tersebut menurut Linuhung \& Sudarman (2016) proses pembelajaran dengan group investigation akan melibatkan siswa secara aktif dalam proses penyelidikan suatu permasalahan. Model pembelajaran Group Investigation merupakan salah satu model pembelajaran yang dapat memfasilitasi siswa meningkatkan kemampuan pemecahan masalah melalui langkah-langkah pembelajaran yang menuntut pemahaman terhadap masalah dan penyelesaian masalah secara terencana.

Menurut Slavin (2005) langkah-langkah Group Investigationterdiri dari 6 langkah yaitu:

1) Mengidentifikasi topik dan mengatur siswa dalam kelompok

Pada tahap ini guru menyiapkan topik yang akan dipelajari oleh siswa. Guru juga dapat memberikan permasalahan-permasalahan yang disajikan dalam bentuk LKS untuk diselesaikan.

2) Merencanakan tugas yang dipelajari

Siswa secara bersama-sama dalam kelompok membuat suatu perencanaan untuk menyelesaikan permasalahan yang diberikan. Siswa berbagi tugas dengan sesama anggota kelompok, siapa yang mengerjakan apa. Hal ini bertujuan agar siswa dapat memanfaatkan waktu yang diberikan sebaikbaiknya untuk menyelesaikan permasalahan yang diberikan dengan baik.

3) Melaksanakan investigasi

Investigasi merupakan suatu proses mencari atau menyelidiki yang dapat dilakukan oleh seseorang/kelompok dan hasil yang diperoleh dari kegiatan investigasi dapat berbeda antara seseorang dengan orang yang lainnya atau antara kelompok yang satu dengan kelompok yang lainnya. Setelah seseorang/kelompok memperoleh hasil dari investigasi maka hasil tersebut dikomunikasikan dan dapat dibandingkan dengan hasil dari kelompok lain. Sehingga dapat ditarik kesimpulan terhadap apa yang diinvestigasi.

4) Menyiapkan laporan akhir

Siswa berkewajiban menyiapkan laporan hasil investigasi yang telah dilakukan. Laporan akhir ini merupakan laporan kelompok, yang berisi tentang apa yang ditemukan setelah melakukan investigasi.

5) Mempresentasikan laporan akhir

Tahap selanjutnya adalah perwakilan siswa mempresentasikan laporan akhir yang telah disiapkan. Siswa yang mempresentasikan laporan dipilih secara acak.

6) Evaluasi 
Setelah siswa melakukan presentasi laporan kelompok maka diharapkan ada umpan balik. Siswa memberikan tanggapan terhadap laporan kelompok yang mempresentasikan hasil investigasinya.

Pada tahap ini guru dapat memberikan tanggapan terhadap hasil investigasi siswa.

Berdasarkan langkah-langkah Group Investigation tersebut, terlihat bahwa proses investigasi merupakan proses untuk memecahkan suatu permasalahan. Menurut Yeo dan Yeap (2010) proses penyelesaian masalah melibatkan proses investigasi. Dengan demikian, setelah melakukan pembelajaran dengan menggunakan pembelajaran Group Investigation diharapkan siswa akan memiliki kemampuan pemecahan masalah yang baik.Tahap investigasi mendorong siswa untuk belajar lebih aktif dalam merumuskan masalah, merencanakan dan menyelesaikan permasalahan dan menarik kesimpulan sementara terhadap hasil investigasi yang telah dilakukan secara berkelompok serta menarik kesimpulan akhir bersama guru. Investigasi menghadirkan keingintahuan siswa serta menuntut siswa untuk menerapkan berbagai ilmu dalam matematika untuk menyelesaikan suatu permasalahan, hal tersebut dapat mengekibatkan banyaknya solusi yang mereka temukan sehingga di akhir nanti mereka harus menentukan solusi yang peling tepat bersama dengan teman 1 kelompok (Diezmann, Watters \& English, 2001).Proses ini akan sangat bermakna bagi siswa karena siswa berperan langsung dalam merumuskan masalah, mencari solusi sampai membuat suatu kesimpulan. Jika siswa menemukan suatu konsep dengan usaha mereka sendiri dengan sedikit bimbingan dari guru maka konsep tersebut akan jauh lebih bermakna dibandingkan dengan menghapal konsep.Jika siswa telah terbiasa melakukan proses pemecahan masalah maka diharapkan siswa mempunyai kemampuan pemecahan masalah yang baik sesuai dengan teori Pavlov tentang konsep pembiasaan (conditioning).

\section{METODE}

Jenis penelitian ini adalah penelitian eksperimen semu atau kuasi eksperimen dengan rancangan penelitianrandomized group only design. Rancangan penelitian ini dapat dilihat pada Tabel 2.

Tabel 2.

Desain Penelitian

\begin{tabular}{lll}
\hline Kelas & Perlakuan & Tes \\
\hline Eksperimen & $\mathrm{X}$ & $\mathrm{T}$ \\
Kontrol & - & $\mathrm{T}$ \\
\hline
\end{tabular}

Sumber: Sugiyono (2011)

Keterangan:

$\mathrm{X}$ : Pembelajaran dengan model kooperatif tipe Group Investigation

$\mathrm{T}:$ Tes kemampuan pemecahan masalah

Populasi pada penelitian ini adalahsiswa Kelas VIII MTs Negeri di Kabupaten Kerinci yang berjumlah 575 orang terdiri dari 26 kelas kecuali kelas VIII unggul di MTs Negeri Kemantan dan MTs Negeri Air Hangat.Menurut Sugiyono (2018) "Populasi adalah generalisasi yang terdiri atas: objek atau subjek yang mempunyai kuantitas dan karakteristik tertentu yang ditetapkan oleh peneliti untuk 
dipelajari dan kemudian ditarik kesimpulannya". Sampel yang diperlukan dalam penelitian ini sebanyak dua kelas yang dipilih berdasarkan teknik sampel acak. Melalui teknik sampel acak, terpilih kelas VIIID MTsN Penawar sebagai kelas eksperimen yang diajar dengan pembelajaran kooperatif tipe Group Investigation dan kelas VIIID MTsN Semerah sebagai kelas kontrol yang diajar dengan pembelajaran biasa.

Pada akhir penelitian, kedua kelas diberikan tes kemampuan pemecahan masalah yang sama. Butir tes akhir yang diberikan telah melalui tahap validasi dan beberapa tahap pengembangan instrumen lainnya, agar butir tes dapat mengukur kemampuan pemecahan masalah.Perangkat tes dikatakan baik jika butir tes yang hasil pengukurannya mampu merepresentasikan keadaan yang sesungguhnya mengenai kemampuan peserta tes pada bidang tertentu yang menjadi sasaran yang akan diukur (Susetyo, 2015).Hasil tes tersebut diskor berdasarkan rubrik penskoran kemampuan pemecahan masalah seperti terlihat pada Tabel 3. Hasil penskoran tes kemampuan pemecahan masalah kemudian dianalisis menggunakanuji Mann Whitney Ukarena asumsi uji-t tidak terpenuhi (data harus normal) (Sugiyono, 2015).

\section{Tabel 3.}

Rubrik Penskoran Soal Kemampuan Pemecahan Masalah Matematis

\begin{tabular}{|c|c|c|}
\hline Indikator & $\begin{array}{l}\text { Jenis Respon } \\
\end{array}$ & Skor \\
\hline \multirow{4}{*}{$\begin{array}{l}\text { Mengidentifikasi unsur-unsur yang } \\
\text { diketahui, yang ditanyakan, dan } \\
\text { kecukupan unsur yang diperlukan }\end{array}$} & Tidak ada jawaban & 0 \\
\hline & $\begin{array}{l}\text { Identifikasi unsur-unsur yang diketahui } \\
\text { tidak sesuai dengan permasalahan yang } \\
\text { ada }\end{array}$ & 1 \\
\hline & $\begin{array}{l}\text { Identifikasi unsur-unsur yang diketahui } \\
\text { sebagian tidak sesuai dengan } \\
\text { permasalahan yang ada }\end{array}$ & 2 \\
\hline & $\begin{array}{lrr}\text { Mengidentifikasi } & \text { unsur-unsur } & \text { yang } \\
\text { diketahui, yang } & \begin{array}{r}\text { ditanyakan, } \\
\text { dan }\end{array} \\
\text { kecukupan unsur yang diperlukan } & \\
\end{array}$ & 3 \\
\hline \multirow{3}{*}{$\begin{array}{l}\text { Merumuskan masalah dan } \\
\text { menyusun model matematika }\end{array}$} & Tidak ada jawaban & 0 \\
\hline & $\begin{array}{l}\text { Tidak tepat dalam merumuskan masalah } \\
\text { matematika dan menyusun model } \\
\text { matematika }\end{array}$ & 1 \\
\hline & $\begin{array}{l}\text { Merumuskan masalah matematika dan } \\
\text { menyusun model matematika dengan } \\
\text { benar dan tepat }\end{array}$ & 2 \\
\hline \multirow{4}{*}{$\begin{array}{l}\text { Menentukan strategi yang tepat } \\
\text { dan menerapkan strategi dalam } \\
\text { menyelesaikan permasalahan }\end{array}$} & Tidak ada jawaban & 0 \\
\hline & $\begin{array}{l}\text { Kurang tepat dalam menentukan strategi } \\
\text { dan menerapkan strategi dalam } \\
\text { menyelesaikan masalah }\end{array}$ & 1 \\
\hline & $\begin{array}{l}\text { Tepat dalam menentukan strategi tetapi } \\
\text { salah dalam menerapkan strategi } \\
\text { penyelesaiannya }\end{array}$ & 2 \\
\hline & $\begin{array}{llr}\text { Menentukan } & \text { strategi dan menerapkan } \\
\text { strategi } & \text { daam } & \text { menyelesaikan } \\
\text { permasalahan benar dan tepat }\end{array}$ & 3 \\
\hline
\end{tabular}

(Dimodifikasi dari Fauzan, 2011) 


\section{HASIL}

\section{Deskripsi data}

Tes akhir dilakukan melalui pemberian tes kemampuan pemecahan masalah yang terdiri dari dua soal essai. Rentang nilai yang dapat diperoleh dari tes ini berkisar dari skor terendah dan skor tertinggi atau skor ideal 16. Hasil penskoran lembar jawaban siswa secara umum dapat dilihat pada Tabel 4.

\section{Tabel 4.}

Data Hasil Pengukuran Tes Pemecahan Masalah Siswa

\begin{tabular}{llllll}
\hline Kelas & $\mathbf{N}$ & $\mathbf{X}_{\text {maks }}$ & $\mathbf{X}_{\min }$ & Rata-rata & Simp. Baku \\
\hline Eksperimen & 19 & 16 & 7 & 11,42 & 2,80 \\
\hline Kontrol & 20 & 14 & 5 & 9,30 & 2,49 \\
\hline
\end{tabular}

Berdasarkan Tabel 4, rata-rata skor tes kemampuan pemecahan masalah siswa kelas eksperimen lebih tinggi dari rata-rata yang diperoleh siswa kelas kontrol. Rata-rata siswa kelas eksperimen adalah 11,42 dengan skor tertinggi yang diperoleh yaitu 16 dan skor terendah adalah 7 sementara rata-rata siswa kelas kontrol adalah 9,3 dengan skor tertinggi yang diperoleh yaitu 14 dan skor terendah adalah 5 dengan simpangan baku 2,80 untuk kelas eksperimen dan 2,49 untuk kelas kontrol.

Berikut ini disajikan salah satu contoh jawaban siswa mengenai soal yang digunakan untuk mengukur kemampuan pemecahan masalah siswa, baik untuk kelas eksperimen maupun untuk kelas kontrol. Hal ini disajikan sebagai gambaran kemampuan yang dimiliki oleh siswa dari kelas eksperimen dan kelas kontrol. Hasil pekerjaan siswa untuk soal pemecahan masalah dapat dilihat pada Gambar 1 dan 2.

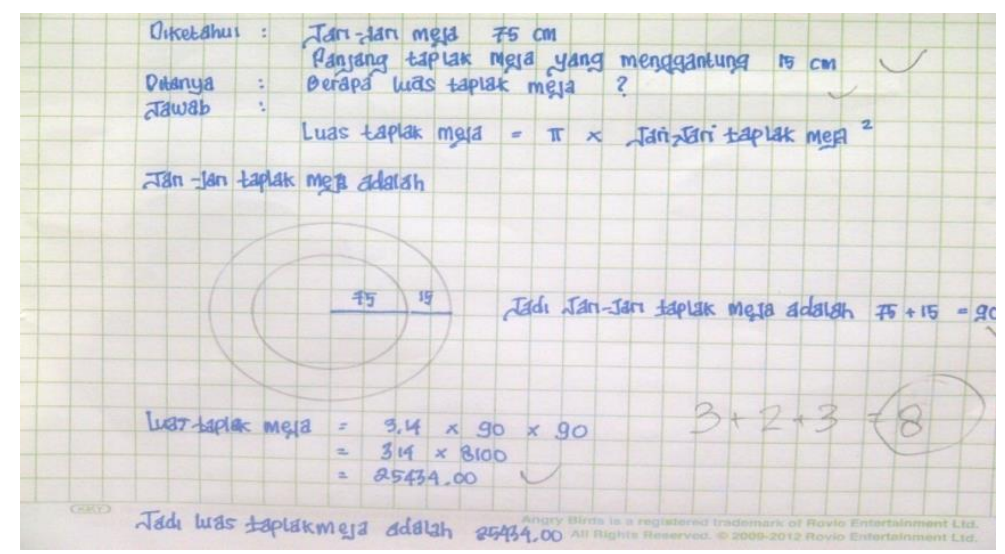

Gambar 1. Contoh Jawaban Siswa Siswa Kelas Eksperimen 


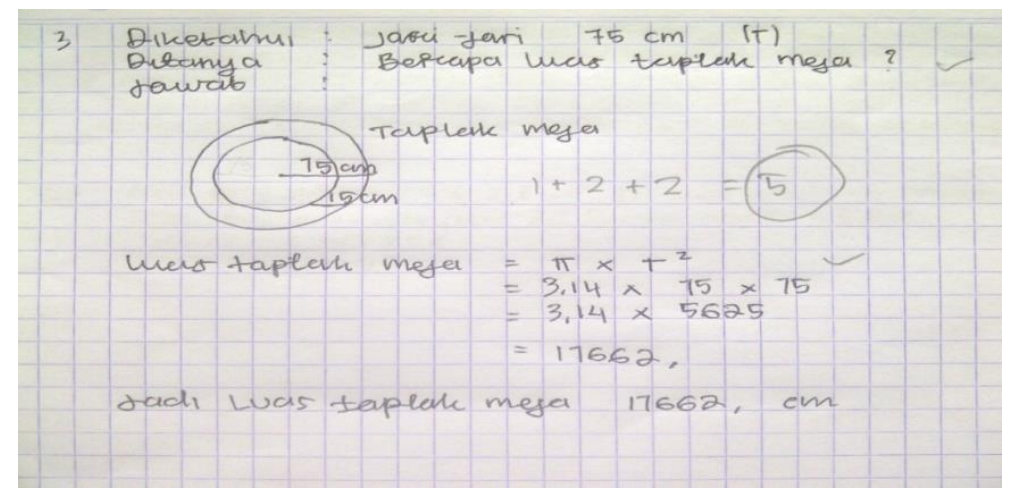

Gambar 2. Contoh Jawaban Siswa Kelas Kontrol

Berdasarkan Gambar 1 dan Gambar 2, terlihat bahwa siswa kelas kontrol belum memahami masalah dengan baik. Siswa kelas kontrol salah dalam mengidentifikasi permasalahan sehingga mengakibatkan kesalahan pada penyelesaian walaupun strategi dan prosedur penyelesaian yang dipilih sudah tepat yaitu dengan cara membuat gambar. Identifikasi masalah akan sangat membantu siswa agar dalam memahami masalah. Melalui tahap identifikasi masalah, siswa akan memahami informasi yang disajikan serta informasi yang belum tersedia tetapi dibutuhkan dalam penyelesaian masalah. Selain itu, pemilihan strategi yang tepat akan mempermudah siswa dalam menyelesaikan permasalahan.

\section{Hasil Tes Rata-Rata Setiap Indikator Pemecahan Masalah}

Perbandingan rata-rata skorsiswa kelas eksperimen dan kelas kontrol pada tiap indikator pemecahan masalah dapat terlihat pada Gambar 3.

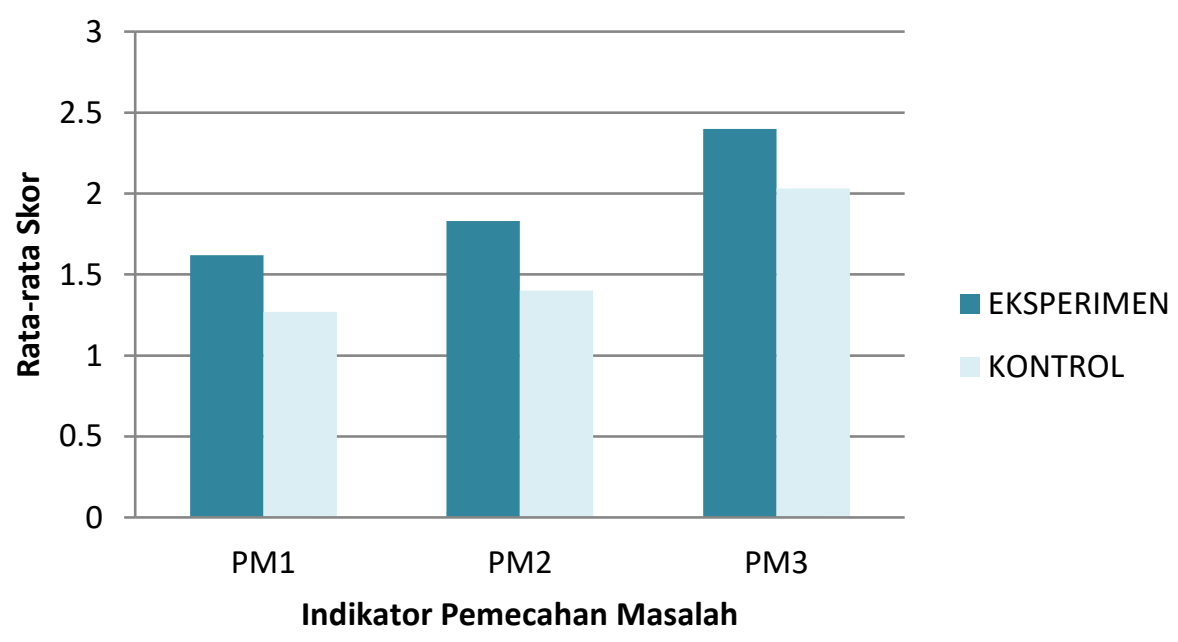

Gambar 3. Rata-rata Skor Setiap Indikator Pemecahan Masalah Siswa Kelas Eksperimen dan Kelas Kontrol (PM1 merujuk pada indikator mengidentifikasi unsur-unsur yang diketahui, yang ditanyakan dan kecukupan unsur yang diperlukan, PM2 merujuk pada indikator merumuskan masalah dan menyusun model matematika dan PM3 merujuk pada indikator menentukan strategi yang tepat dan menerapkan strategi dalam menyelesaikan permasalahan)

Gambar 3 menunjukkan bahwa skor rata-rata yang diperoleh siswa kelas eksperimen pada tiap indikator pemecahan masalah lebih tinggi dari skor rata-rata yang diperoleh siswa kelas kontrol yaitu di kelas eksperimen. Pada indikator mengidentifikasi unsur-unsur yang diketahui, yang ditanyakan dan 
kecukupan unsur yang diperlukan, siswa pada kelas eksperimen mendapat skor rata-rata 1,62 atau lebih tinggi 0,35 dibandingkan skor rata-rata yang diperoleh siswa pada kelas kontrol yaitu 1,27. Sedangkan pada indikator indikator merumuskan masalah dan menyusun model matematika dan indikator menentukan strategi yang tepat dan menerapkan strategi dalam menyelesaikan permasalahan siswa kelas eksperimen mendapat skor rata-rata masing-masing 1,83 dan 2,4. Hal yang berbeda terlihat bahwa siswa kelas kontrol hanya memperoleh skor rata-rata 1,4 dan 2,03 pada masing-masing indikator kedua dan ketiga.

\section{Uji Normalitas}

Uji normalitas dilakukan terhadap nilai tes kemampuan pemecahan masalah siswa kelas eksperimen dan kelas kontrol. Kriterianya adalah jika nilai Sig. lebih besar dari taraf nyata $(\alpha=0,05)$ maka data berdistribusi normal dan sebaliknya. Hasil pengujian normalitas kemampuan pemecahan masalah dapat dilihat pada Tabel 5 .

\section{Tabel 5.}

Hasil Uji Normalitas Terhadap Nilai Tes Kemampuan Matematis Siswa

\begin{tabular}{lll}
\hline Kelas & Sig. & Keterangan \\
\hline Eksperimen & 0,127 & Normal \\
\hline Kontrol & 0,039 & Tidak Normal \\
\hline
\end{tabular}

\section{Uji Hipotesis}

Hipotesis yang diajukan dalam penelitian ini adalah bahwa kemampuan pemecahan masalah matematis siswa yang mengikuti pembelajaran dengan kooperatif tipe Group Investigation lebih tinggi dari kemampuan pemecahan masalah siswa yang mengikuti pembelajaran biasa. Uji statistik yang digunakan untuk hipotesis tersebut adalah uji Mann Whitney $U$ karena data tidak berdistribusi secara normal. Berikut disajikan hasil uji hipotesis dengan menggunakan uji Mann Whitney $U$.

\section{Tabel 6.}

Hasil Uji Perbedaan Rata-Rata Skor Tes Pemecahan Masalah Siswa Kelas Eksperimen dan Kontrol

\begin{tabular}{llll}
\hline Kelas & N & Rata-rata & Sig. \\
\hline Eksperimen & 19 & 11,42 & 0,0065 \\
\hline Kontrol & 20 & 9,30 & \\
\hline
\end{tabular}

Pada tabel 6 terlihat bahwa sig. $<0,05$ yaitu 0,0065, nilai sig. ini diperoleh dari transformasi uji dua arah ke uji satu arah dengan cara membagi dua nilai sig yang diperoleh dari hasil analisis menggunakan SPSS, ini berarti $\mathrm{H}_{0}$ ditolak sehingga dapat disimpulkan bahwa kemampuan pemecahan masalah matematis siswa yang mengikuti pembelajaran dengan kooperatif tipe Group Investigation lebih tinggi dari kemampuan pemecahan masalah siswa yang mengikuti pembelajaran biasa. 


\section{Kemampuan Pemecahan Masalah Siswa Kelas Eksperimen dan Kelas Kontrol}

Berdasarkan pengujian hipotesis diperoleh kesimpulan bahwa kemampuan pemecahan masalah siswa yang mengikuti pembelajaran dengan kooperatif tipe Group Investigation lebih tinggi dari kemampuan pemecahan masalah siswa yang mengikuti pembelajaran biasa. Hal ini dikarenakan pada pembelajaran dengan model kooperatif tipe Group Investigation siswa diarahkan untuk memahami suatu permasalahan dengan cara mencari informasi sebanyak-banyaknya berkaitan dengan permasalahan yang ada. Informasi dapat diperoleh dari berbagai sumber misalnya buku, guru atau teman dalam satu kelompok. Kemudian informasi yang diperoleh didiskusikan guna merumuskan permasalahan sehingga dapat disusun strategi yang tepat untuk menyelesaikannya.

Proses inilah yang terindikasi menyebabkan siswa pada kelas eksperimen terbiasa melakukan identifikasi masalah. Jika siswa dihadapkan pada soal, siswa akan mencari informasi-informasi yang ada pada soal baik yang diketahui, yang dibutuhkan maupun yang ditanyakan.Dari lembar jawaban siswa setelah menyelesaikan soal-soal yang diberikan, terlihat bahwa siswa kelas eksperimen melakukan identifikasi masalah terlebih dahulu sebelum menerapkan strategi untuk menyelesaikannya. Dengan identifikasi masalah akan terlihat informasi apa saja yang disajikan pada soal, informasi ini akan membantu siswa dalam memahami soal yang ada. Selain mencari informasi yang ada pada soal, identifikasi masalah juga mencari apa yang sebenarnya ditanyakan pada soal, hal ini akan mempermudah siswa merumuskan permasalahan dan menentukan strategi yang tepat untuk menyelesaikannya.

Sebagai contoh, pada Gambar 1 siswa kelas eksperimen memilih strategi membuat gambar. Pemilihan strategi membuat gambar sangat tepat digunakan karena dengan gambar siswa akan mudah menentukan unsur yang diperlukan yaitu jari-jari taplak meja yang akan berguna untuk menentukan luas taplak meja tersebut. Dari Gambar 1 dan Gambar 2 terlihat perbedaan antara jawaban siswa kelas eksperimen menyelesaikan masalah dengan siswa kelas kontrol, siswa kelas eksperimen menyelesaikan soal mulai dari identifikasi masalah sampai pada penerapan strategi. Hampir sama dengan siswa kelas eksperimen namun siswa kelas kontrol salah dalam mengidentifikasi masalah sehingga membawa siswa pada jawaban yang salah.

Kondisi di atas juga menyebabkan perbedaan rata-rata untuk setiap indikator yang diperoleh siswa kelas eksperimen dan kelas kontrol yaitu, rata-rata untuk setiap indikator dari hasil tes kemampuan pemecahan masalah siswa yang diajar dengan pembelajaran kooperatif tipe Group Investigation lebih tinggi dari rata-rata setiap indikator dari hasil tes kemampuan pemecahan masalah siswa yang diajar dengan pembelajaran biasa, untuk lebih jelas dapat dilihat pada Gambar 3.

Perbedaan yang terjadi antara cara siswa kelas eksperimen menjawab soal dengan siswa kelas kontrol dikarenakan pembelajaran yang diterapkan di kelas. Berbeda dengan pembelajaran kooperatif tipe Group Investigation, pembelajaran biasa yang dilakukan di kelas kontrol tidak banyak melibatkan siswa secara aktif, guru masih memegang peranan yang cukup banyak dalam pembelajaran di kelas. Guru menjelaskan meteri beserta contoh soal selanjutnya meminta siswa mengerjakan beberapa soal 
sebagai latihan. Proses pembelajaran seperti ini akan membiasakan siswa untuk menghafal sehingga konsep yang diajarkan oleh guru tidak melekat dengan baik diingatan siswa. Siswa akan kesulitan jika dihadapkan pada suatu soal yang berbeda dengan yang dicontohkan oleh guru padahal dalam penyelesaiannya masih menggunakan konsep yang sama dengan yang telah dijelaskan sebelumnya.

Anggraini, Siroj \& Putri(2010) juga menemukan hasil yang sama dalam penelitian tentang penerapan pembelajaran investigasi kelompok untuk meningkatkan kemampuan pemecahan masalah matematika siswa kelas VIII-4 SMP Negeri 27 Palembang. Penelitian tersebut mengungkapkan bahwa dengan menerapkan model investigasi kelompok pada proses pembelajaran maka kemampuan pemecahan masalah matematika siswa mengalami peningkatan yang dapat dilihat dari rata-rata kemampuan siswa memecahkan masalah matematika pada siklus pertama yaitu 66 meningkat menjadi 76 pada siklus kedua.

Group Investigation dapat meningkatkan kemampuan pemecahan masalah matematis siswa, karena investigasi sebagai proses memiliki 4 (empat) tahapan proses berfikir, menurut Yeo dan Yeap dalam Lidinillah (2008) berdasarkan literatur yang mereka analisis, yaitu spesialisasi, pengajuan dugaan (conjecturing), mempertimbangkan (justification), dan generalisasi. Proses spesialisasi erat kaitannya dengan proses identifikasi, dengan proses ini siswa akan dilatih untuk memahami suatu permasalahan. Begitu juga dengan pengajuan dugaan yang akan dibuktikan kebenarannya dapat melatih siswa untuk memilih strategi yang tepat dalam pembuktian sehingga hasilnya dapat dijadikan suatu kesimpulan.

Senada dengan pernyataan di atas, Tim Instruktur PKG Matematika SMU dalam Setiawan (2006) menyatakan bahwa pemecahan masalah dan investigasi pada prinsipnya mempunyai aktivitas yang hampir sama, keduanya saling berkaitan dan memerlukan siswa untuk menemukan sesuatu, merumuskan hipotesis, dan mencapai suatu kesimpulan sendiri. Artinya jika siswa diajarkan dengan menggunakan pembelajaran Group Investigation siswa akan terbiasa untuk malakukan kegiatan yang berkaitan dengan memecahkan masalah, sehingga dapat meningkatkan kemampuan pemecahan masalah siswa sesuai dengan teori Pavlov tentang konsep pembiasaan.

\section{KESIMPULAN}

Dari hasil penelitian serta analisis data yang telah dilakukan maka dapat disimpulkan bahwa model pemebelajaran kooperatif tipe Group Investigation memberi pengaruh terhadap kemampuan pemecahan masalah, hal ini dapat dilihat dari skor rata-rata kemampuan pemecahan masalah matematis siswa berkemampuan yang mengikuti pembelajaran dengan kooperatif tipe Group Investigation lebih tinggi dari skor rata-rata kemampuan pemecahan masalah siswa yang mengikuti pembelajaran biasa.

DAFTAR PUSTAKA (Gunakan Microsoft Word template style: Heading 1)

Ahmad, B., Deswita, R., Ningsih, F \& Syafriadi (2017). Pengaruh Model Pembelajaran CORE dengan Pendekatan Scientific terhadap Kemampuan Pemecahan Masalah Matematis dan Mathematical Habits Of Mind Mahasiswa Matematika. Tarbawi: Jurnal Ilmu Pendidikan, 13(2), 33-42 
Anggraini, L., Siroj, R. A., \&Putri, R. I. I (2010). Penerapan Model Pembelajaran Investigasi Kelompok untuk Meningkatkan Kemampuan Pemecahan Masalah Matematika Siswa Kelas VIII-4 SMP Negeri 27 Palembang.Jurnal Pendidikan Matematika, 4(1), 33-44.

Asnawati, S., Sanusi, N. M. R., \& Noto, M. S. (2018). Pemecahan Masalah Matematis Berdasarkan Kemampuan Awal Matematis Melalui Pembelajaran Grup Investigasi Berbantuan Geogebra Matakuliah Geometri Analitik. UNION: Jurnal Ilmiah Pendidikan Matematika, 6(2), 157-166.

Diezmann, C. M., Watters, J. J., \& English, L. D. (2001).Implementing Mathematical Investigations With Young Children. In Proceedings 24th Annual Conference of the Mathematics Education Research Group of Australasia. Sydney. 170-177

Fauzan, A. (2011). Modul Evaluasi Pembelajaran Matematika: Pemecahan Masalah Matematika. Padang: Universitas Negeri Padang Press.

Lestari, K. E., \& Yudhanegara, M. R. (2015). Penelitian Pendidikan Matematika. Bandung: PT Refika Aditama.

Lidinillah, D. A. M. (2008). Kegiatan Investigasi dalam Pembelajaran Matematika di Sekolah Dasar.Jurnal Penelitian dan Pengembangan Pendidikan, 4(1).

Linuhung, N., \& Sudarman, S. W. (2016). Pengaruh Pembelajaran Kooperatif Tipe Group Investigation (GI) Terhadap Kemampuan Penalaran Matematis Siswa MTs. AKSIOMA: Jurnal Program Studi Pendidikan Matematika, 5(1), 52-60.

Meditamar, M. O., Gunawan, R. G., Oktafia, M., \& Nurmailis, N. (2017). Pengaruh Strategi Belajar Murder dengan Setting Belajar Kelompok Terhadap Kemampuan Pemecahan Masalah Matematika Siswa SMP Negeri 1 Kerinci. Tarbawi: Jurnal Ilmu Pendidikan, 13(1), 11-21.

Mushoddik, M., Utaya, S., \& Budijanto, B. (2017). Pengaruh Model Pembelajaran Group Investigation Terhadap Kemampuan Berpikir Kritis Siswa MAN 6 Jakarta. JURNAL SWARNABHUMI: Jurnal Geografi dan Pembelajaran Geografi, 1(1).

National Council of Teachers of Mathematics (Ed.).(2000). Principles and Standarts for School Mathematics (Vol. 1). Reston, VA: NCTM.

Prahmana, R. C. I. (2015). Mengenal Matematika Lebih Dekat. Yogjakarta: Ruko Jambusari.

Pranata, E. (2016). Implementasi Model Pembelajaran Group Investigation (GI) Berbantuan Alat Peraga Untuk Meningkatkan Kemampuan Pemahaman Konsep Matematika. JPMI (Jurnal Pendidikan Matematika Indonesia), 1(1), 34-38.

Setiawan. (2006). Model Pembelajaran Matematika dengan Pendekatan Investigasi. Yogyakarta: Pusat Pengembangan dan Penataran Guru Matematika.

Slavin, R. (2005). Cooperative Learning: Teori, Riset dan Praktik. Bandung: Nusa Media.

Sunendar, A. (2017). Pembelajaran Matematika dengan Pemecahan Masalah. Jurnal THEOREMS, 2(1), 86-93

Sugiyono.(2011). Metode Penelitian Pendidikan. Bandung: Alfabeta. .(2015). Statistik Nonparametris Untuk Penelitian.Bandung: Alfabeta. 
.(2018). Metode Penelitian Kuantitatif. Bandung: Alfabeta.

Susetyo, B. (2015). Prosedur Penyusunan dan Analisis Tes. Bandung: Refika Aditama.

Ulandari, N., Putri, R., Ningsih, F., \& Putra, A. (2019). Efektivitas Model Pembelajaran Inquiry terhadap Kemampuan Berpikir Kreatif Siswa pada Materi Teorema Pythagoras. Jurnal Cendekia: Jurnal Pendidikan Matematika, 3(2), 227-237.

Wulansari, T., Putra, A., Rusliah, N., \& Habibi, M. (2019). Pengaruh Model Pembelajaran Berbasis Masalah pada Materi Statistika Terhadap Kemampuan Penalaran Statistik Siswa. AKSIOMA: Jurnal Matematika dan Pendidikan Matematika, 10(1), 35-47.

Yeo, J. B., \& Yeap, B. H. (2010). Characterising the Cognitive Processes in Mathematical Investigation. International Journal for Mathematics Teaching and Learning. Retrieved from: http://www.cimt.plymouth.ac.uk/journal/jbwyeo.pdf 